\title{
Performance and immunological resistance of Litopenaeus vannamei fed a $\beta-1,3 / 1,6$-glucan-supplemented diet after per os challenge with the Infectious myonecrosis virus (IMNV)
}

\author{
Hassan Sabry Neto ${ }^{1}$, Alberto Jorge Pinto Nunes ${ }^{1}$ \\ ${ }^{1}$ Universidade Federal do Ceará, Instituto de Ciências do Mar, Fortaleza, CE, Brasil.
}

\begin{abstract}
This study determined the efficacy of a $\beta-1,3 / 1,6$-glucan source on the survival, growth, and immunological responses of Litopenaeus vannamei challenged with infectious myonecrosis virus (IMNV). The work was conducted in 20 tanks of $500 \mathrm{~L}$ with clear water with constant recirculation and aeration. Shrimp weighing $2.6 \pm 0.4 \mathrm{~g}$ were stocked at 100 animals $/ \mathrm{m}^{2}$ and reared for 10 weeks. Viral challenge occurred through oral administration of IMNV positive extract ( $1.82 £ \times 103$ copies of IMNV/ $\mu \mathrm{L}$ RNA) during three consecutive days, twice a day. One treatment and three controls, with five replicate tanks each, were used, as follows: Com - commercial diet fed to non-challenged shrimp (NCS); Ref - lab-manufactured basal diet, deprived of $\beta$-1,3/1,6-glucan fed to NCS; IMNV-Ref - basal diet fed to IMNV-challenged shrimp; and, IMNV-BetG - basal diet with $1,000 \mathrm{mg} / \mathrm{kg}$ of a $\beta-1,3 / 1,6$-glucan. Per os challenge began on the 29 th day of rearing (4.93-g to 6.92-g shrimp). Shrimp were effectively contaminated with IMNV. Animals were highly susceptible to IMNV four weeks after the first day of infection when mortality peaked. Shrimp in the Com treatment $(69.5 \pm 12.7 \%)$ reached the highest survival, but it did not differ from

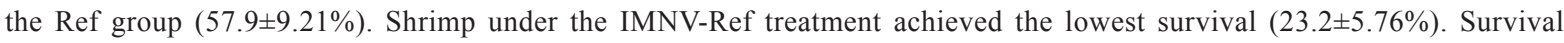
for IMNV-BetG $(48.1 \pm 8.53 \%)$ was significantly higher than IMNV-Ref, and similar to the Ref group. Total hemocyte count was significantly affected by treatment and hemolymph sampling time, while serum protein concentration and phenoloxidase activity did not change. Addition of $1,000 \mathrm{mg} / \mathrm{kg}$ of $\beta-1,3 / 1,6$-glucan in a diet for $L$. vannamei enhances shrimp survival when orally exposed to IMNV. No signs of immunological fatigue or detriment in growth are detected when the species is continually exposed to this diet.
\end{abstract}

Key Words: betaglucan, shrimp

\section{Introduction}

The first viral disease in a cultivated penaeid species was reported in 1974 (Baculovirus penaei, or BP; Couch, 1974 a,b). Thirteen years later, in 1987, farm-reared shrimp production suffered its first significant collapse in Taiwan (Lightner et al., 1987; Lin, 1989). Since then, pandemic viral outbreaks have increased, causing profound social and economical impacts in shrimp industries located in developing countries (Lightner, 2003).

In Brazil, farming of Litopenaeus vannamei was first disrupted by a virus in 2003 after a 5-year continuous growth that led to a 90,000 MT record in annual production. An endemic and new agent named Infectious myonecrosis virus (IMNV) was found to be the cause of shrimp mortalities in farms of Northeast Brazil (Lightner et al., 2004a,b; Poulos et al., 2006; Andrade et al., 2007).

Received November 28, 2014 and accepted March 17, 2015

Corresponding author: alberto.nunes@ufc.br

http://dx.doi.org/10.1590/S1806-92902015000500001

Copyright $(\subset 2015$ Sociedade Brasileira de Zootecnia. This is an Open Access article distributed under the terms of the Creative Commons Attribution Non-Commercial License, which permits unrestricted non-commercial use, distribution, and reproduction in any medium, provided the original work is properly cited.
The early reports of IMNV indicated loss of transparency in the abdominal tissue of $L$. vannamei often leading to a reddish color, coupled with a persistent daily mortality after shrimp reached $7 \mathrm{~g}$ (Lightner, 2004a,b; Nunes et al., 2004). Cumulative mortalities approached $70 \%$ after a typical 120-day grow-out cycle resulting in a food conversion ratio well above 2.0 for 12- to 14-g shrimp (Nunes et al., 2004). The viral origin of the disease was confirmed by the University of Arizona aquatic pathology team, after infectivity bioassays and studies on electronic microscopy and genomic analyses (Lightner et al., 2004a,b; Poulos and Lightner, 2006; Poulos et al., 2006). In 2006, IMNV was also detected in Indonesia (Senapin et al., 2007) and is now a notifiable disease by OIE (Office International des Epizooties).

To date no single effective treatment against shrimp viral diseases exists. As shrimp are not able to respond to vaccination, enhancement of disease resistance has been attempted through stimulation of the immunological system. Several compounds have been reported to actively promote immunological responses and increase survival in cultured penaeids after viral or bacterial challenge. This includes peptidoglycans (Itami et al., 1998), glucans (Sung et al., 1994; 
Song et al., 1997; Huang and Song, 1999; Chang et al., 2000; Lópezetal., 2003; Rodríguezetal., 2007), lipopolysaccharides (Sritunyalucksana et al., 1999; Takahashi et al., 2000), and sulfated fucoidans (Chotigeat et al., 2004).

Studies on IMNV have evolved on the viral genome characterization and sequencing (Poulos et al., 2006; Senapin et al., 2007) and on the development of diagnostic tools (Tang et al., 2005; Poulos and Lightner, 2006; Andrade et al., 2007; Senapin et al., 2007). The present study aimed at determining if a $\beta-1,3 / 1,6$-glucan extracted from the cellular wall of the baker's yeast Saccharomyces cerevisiae could promote an increase in survival and immunological resistance in L. vannamei after a per os challenge with IMNV.

\section{Material and Methods}

The study was conducted in the city of Eusébio, state of Ceará, Brazil (geographical coordinates $35^{\circ} 00^{\prime} 0.25^{\prime \prime} \mathrm{S}$ and $\left.38^{\circ} 25^{\prime} 22.57^{\prime \prime} \mathrm{W}\right)$. A total of 20 circular 500 -L polypropylene tanks were used. Tanks were organized in four unit cells placed next to each other. Each cell consisted of five tanks individually served by a $45-\mathrm{kg}$ sand filter and a 0.25 -hp water pump. Continuous aeration was supplied by two 2.0-hp air blowers and air diffusers. Five tanks per treatment or control were used. Prior to shrimp stocking, the culture system (tanks, sand filters, aeration, and water lines) was washed and disinfected with a solution of freshwater and calcium hypochlorite at $100 \mathrm{ppm}$ (65\% of active chlorine; $\mathrm{HTH}^{\circledR}$, Nordesclor S.A., Igarassu, Brazil). Disinfection extended to the culture water (20 ppm) and feeding trays (30 ppm).

In the present study, shrimp growth, survival and selected immunological parameters of juvenile L. vannamei orally challenged with IMNV were evaluated. Shrimp were fed lab-manufactured diets either deprived or containing a source of $\beta-1,3 / 1,6$-glucan. The $\beta-1,3 / 1,6$-glucan used was a commercial polysaccharide extracted and purified from the cellular wall of the baker's yeast Saccharomyces cerevisiae (MacroGard ${ }^{\circledR}$, Immunocorp AS, Oslo, Norway).

The experimental design comprised one treatment and three control diets (Table 1), as follows: Com, a highperformance commercial diet fed to IMNV-free shrimp (Camaronina 35 hp, Cargill Nutrição Animal Ltda., São Lourenço da Mata, Brazil); Ref, a basal diet manufactured in the lab, deprived of $\beta-1,3 / 1,6$-glucan and fed to IMNVfree shrimp; IMNV-Ref, the basal diet fed to shrimp per os challenged with IMNV; and IMNV-BetG, the basal diet with inclusion of $1,000 \mathrm{mg} / \mathrm{kg}$ of a commercial $\beta$-1,3/1,6-glucan.

The experimental diets were formulated using Feedsoft Professional v3.10 (Feedsoft Corporation, Richardson,
Texas, USA). The nearly isocaloric and isoproteic diets were designed to result in the same nutritional composition except in regard to the inclusion of a $\beta-1,3 / 1,6$-glucan source. The $\beta-1,3 / 1,6$-glucan used was included in the IMNV-BetG diet at the expense of bentonite (Table 2). Diets were manufactured with laboratory-scale feed equipment as described by Browdy et al. (2012).

Four thousand L. vannamei juveniles $(2.6 \pm 0.4 \mathrm{~g}$; mean \pm standard deviation; $\mathrm{n}=11$ ) were obtained from a commercial shrimp farm (Amontada, state of Ceará, Brazil) and transported to the lab facilities. In the lab, animals were stocked in rearing tanks at 57 shrimp $/ \operatorname{tank}\left(100 \mathrm{shrimp} / \mathrm{m}^{2}\right)$. To check the pathological status of stocked shrimp, a pool of 30 animals were collected for histopathology. Shrimp were analyzed according to Lightner (1996). PCR (Polymerase Chain Reaction) analysis was carried out on the third pair of shrimp pleopods previously fixed in a 95\% ethanol solution. Shrimp were screened for Taura syndrome virus (TSV), White spot syndrome virus (WSSV), Infectious hypodermal and hematopoietic necrosis virus (IHHNV), and Infectious myonecrosis virus (IMNV). PCR evaluation was carried out according to the following protocols: TSV by Nunan et al. (1998); WSSV by Lo et al. (1996); IHHNV by Nunan et al. (2000); IMNV by Poulos and Lightner (2006). Histopathology and PCR results indicated stocked shrimp were free of TSV, WSSV, IHHNV, and IMNV.

Initially, shrimp were fed for 10 days a $33 \% \mathrm{CP}$ (crude protein) lab-made diet. After the acclimation period, animals were fed their respective experimental diets for 70 days. Over the growth cycle, shrimp were exposed to the feed for $5 \mathrm{~h}$ daily (from 07.30 to $10.00 \mathrm{~h}$ and from 13.30 to $16.00 \mathrm{~h}$ ). Meals were split equally between the two feeding times. Feed not consumed within $2.5 \mathrm{~h}$ after delivery was collected, weighed, and discarded. Feed was only delivered

Table 1 - Experimental design adopted during the study with $L$. vannamei challenged with the Infectious myonecrosis virus (IMNV)

\begin{tabular}{lcc}
\hline Treatment & $\begin{array}{c}\text { IMNV per os } \\
\text { challenge }\end{array}$ & $\begin{array}{c}\beta-1,3 / 1,6 \text {-glucan } \\
\text { supplementation }\end{array}$ \\
\hline Com $^{3}$ & No & - \\
Ref $^{4}$ & $\mathrm{No}^{5}$ & No \\
IMNV-Ref $^{6}$ & Yes & No \\
IMNV-BetG $^{7}$ & Yes & $1,000 \mathrm{mg} / \mathrm{kg}$ \\
\hline
\end{tabular}

${ }^{1}$ Shrimp per os challenge with the Infectious myonecrosis virus (IMNV).

${ }^{2}$ Commercial polysaccharide extracted and purified from the cellular wall of the baker's yeast Saccharomyces cerevisiae with $60 \%$ of active $\beta-1,3 / 1,6$-glucan (Raa, 2000, 2003).

${ }^{3}$ Commercial pelleted shrimp feed (with $35 \%$ crude protein; Camaronina $35 \mathrm{hp}$ Cargill Nutrição Animal Ltda., São Lourenço da Mata, Brazil).

${ }^{4}$ Lab-manufactured pelleted diet with $31.4 \%$ crude protein (basal diet).

${ }^{5}$ Although shrimp were not intentionally challenged with IMNV, PCR analysis indicated shrimp were IMNV-positive at harvest.

${ }^{6}$ Basal diet fed to IMNV-challenged shrimp.

${ }^{7}$ Basal diet containing $1,000 \mathrm{mg} / \mathrm{kg}$ of a commercial $\beta-1,3 / 1,6$-glucan. 
Table 2 - Composition and chemical proximate values of diets used in the study

\begin{tabular}{|c|c|c|c|}
\hline \multirow{2}{*}{ Ingredients } & \multicolumn{3}{|c|}{ Feed $(\mathrm{g} / \mathrm{kg}$ of diet $)$} \\
\hline & Ref or IMNV-Ref & IMNV-BetG & Com \\
\hline Wheat flour ${ }^{1}$ & 350.00 & 350.00 & - \\
\hline Soybean meal ${ }^{2}$ & 220.79 & 220.79 & - \\
\hline Broken rice ${ }^{3}$ & 70.00 & 70.00 & - \\
\hline Fishmeal, anchovy ${ }^{4}$ & 167.11 & 167.11 & - \\
\hline Fishmeal, Brazilian ${ }^{5}$ & 100.00 & 100.00 & - \\
\hline Fish oil ${ }^{6}$ & 30.00 & 30.00 & - \\
\hline Soy lecithin ${ }^{7}$ & 20.00 & 20.00 & - \\
\hline Cholesterol $^{8}$ & 1.50 & 1.50 & - \\
\hline Attractant $^{9}$ & 5.00 & 5.00 & - \\
\hline Common salt & 10.00 & 10.00 & - \\
\hline Vitamin-mineral premix ${ }^{10}$ & 10.00 & 10.00 & - \\
\hline Synthetic binder ${ }^{11}$ & 5.00 & 5.00 & - \\
\hline Dicalcium phosphate & 12.00 & 12.00 & - \\
\hline Bentonite & 3.60 & 2.60 & - \\
\hline$\beta$-1,3/1,6-glucan ${ }^{12}$ & 0.00 & 1.00 & - \\
\hline \multicolumn{4}{|l|}{ Chemical composition $^{13}$} \\
\hline Crude protein $(\mathrm{g} / \mathrm{kg})$ & 314 & 313 & 366 \\
\hline Crude fat $(\mathrm{g} / \mathrm{kg})$ & 101 & 100 & 87 \\
\hline $\operatorname{Ash}(g / k g)$ & 100 & 103 & 106 \\
\hline Crude fiber $(\mathrm{g} / \mathrm{kg})$ & 51 & 43 & 76 \\
\hline Gross energy $(\mathrm{kcal} / \mathrm{kg})^{14}$ & 3,706 & 3,817 & 3,713 \\
\hline
\end{tabular}

${ }^{1} 130.4 \mathrm{~g} / \mathrm{kg}$ crude protein $(\mathrm{CP}) ; 12.3 \mathrm{~g} / \mathrm{kg}$ crude fat $(\mathrm{CF}) ; 7.8 \mathrm{~g} / \mathrm{kg}$ ash; $0.6 \mathrm{~g} / \mathrm{kg}$ crude fiber (CF); 4,306 kcal/kg gross energy (GE).

${ }^{2} 500.0 \mathrm{~g} / \mathrm{kg} \mathrm{CP} ; 21.0 \mathrm{~g} / \mathrm{kg} \mathrm{CF} ; 101.2 \mathrm{~g} / \mathrm{kg}$ ash; $77.4 \mathrm{~g} / \mathrm{kg} \mathrm{CF} ; 4,722 \mathrm{kcal} / \mathrm{kg} \mathrm{GE}$.

${ }^{3}$ Usina Catende (Catende, Brazil). $92.1 \mathrm{~g} / \mathrm{kg} \mathrm{CP} ; 10.6 \mathrm{~g} / \mathrm{kg} \mathrm{CF} ; 6.3 \mathrm{~g} / \mathrm{kg}$ ash; $12.1 \mathrm{~g} / \mathrm{kg} \mathrm{CF}$; $4,250 \mathrm{kcal} / \mathrm{kg} \mathrm{GE}$.

${ }^{4}$ Pesquera Capricornio S.A. (Lima, Peru). 688.7 g/kg CP; 71.5 g/kg CF; 166.7 g/kg ash; $54.6 \mathrm{~g} / \mathrm{kg} \mathrm{CF} ; 4,957 \mathrm{kcal} / \mathrm{kg} \mathrm{GE}$.

${ }^{5}$ ETNA Agro Indústria Ltda. (Capela de Santana, Brazil). 582.2 g/kg CP; 81.8 g/kg CF; $279.6 \mathrm{~g} / \mathrm{kg}$ ash; $8.5 \mathrm{~g} / \mathrm{kg} \mathrm{CF} ; 4,547 \mathrm{kcal} / \mathrm{kg} \mathrm{GE}$.

${ }^{6} 980.0 \mathrm{~g} / \mathrm{kg} \mathrm{CF} ; 8,620 \mathrm{kcal} / \mathrm{kg} \mathrm{GE}$.

${ }^{7} 1,000.0 \mathrm{~g} / \mathrm{kg} \mathrm{CF} ; 7,590 \mathrm{kcal} / \mathrm{kg} \mathrm{GE}$.

${ }^{8}$ Cholesterol XG, Dishman Netherlands B.V. (Veenendaa, the Netherlands). $91 \mathrm{~g} / \mathrm{kg}$ active cholesterol.

${ }^{9}$ Aquasavor ${ }^{\mathrm{TM}}$, Bentoli Agrinutrition Inc. (Texas, USA).

${ }^{10}$ Rovimix Camarao Intensivo. DSM Produtos Nutricionais Brasil Ltda., São Paulo, Brazil. Guarantee levels per kg of product: vitamin A - 1,250,000 IU; vitamin D3 350,000 IU; vitamin E - 25,000 UI; vitamin K3 - 500.0 mg; vitamin B1 - 5,000.0 mg; vitamin B2 - 4,000.0 mg; vitamin B6 - $10.0 \mathrm{mg}$; nicotinic acid - 15,000.0 mg; pantothenic acid - 10,000.0 mg; biotin - $150.0 \mathrm{mg}$; folic acid - 1,250.0 mg; vitamin C - 25,000.0 mg; choline - 50,000.0 mg; inositol - 20,000.0 mg; iron - 2,000.0 mg; copper - 3,500.0 mg; copper chelate - 1,500,0 mg; zinc - 10,500.0 mg; zinc chelate $4,500.0 \mathrm{mg}$; manganese $-4,000.0 \mathrm{mg}$; selenium $-15.0 \mathrm{mg}$; selenium chelate $-15.0 \mathrm{mg}$; iodine - $150.0 \mathrm{mg}$; cobalt $-30.0 \mathrm{mg}$; chromium - $80.0 \mathrm{mg}$; filler - $1,000.0 \mathrm{~g}$.

${ }^{11}$ Pegabind ${ }^{\mathrm{TM}}$, Bentoli Agrinutrition Inc. (Texas, USA). Synthetic pellet binder.

${ }^{12}$ Macrogard $^{\circledR}$ (Biorigin, Oslo, Norway. $60 \%$ purified $\beta-1,3 / 1,6$-glucan (Seljelid et al., 1981).

${ }^{13}$ Composition analyzed by standard methods (AOAC, 1990); dry matter basis.

${ }^{14}$ Measured in ground samples of 8 to $12 \mathrm{mg}$ by wet combustion when the amount of oxygen expanded in the combustion was converted to energy (Karzinkin and Tarkovskaya, 1964).

in a $150-\mathrm{mm}$ diameter feeding tray, installed at one unit per tank. Feeding rates in each tank followed the guidelines presented by Nunes and Parsons (2000). Feed rations were adjusted at biweekly intervals, after shrimp weighing. On Sundays, shrimp were fed only once at $07.30 \mathrm{~h}$ with half of the estimated daily ration. In this case, all unconsumed feed, if any, was only collected the next day.

Tank water temperature, salinity, and $\mathrm{pH}$ were monitored daily with portable water quality meters at $15.00 \mathrm{~h}$. Mean values observed were $28.4 \pm 0.09^{\circ} \mathrm{C}(\mathrm{n}=1,800) ; 34.8 \pm 0.41 \mathrm{ppt}$ $(\mathrm{n}=1,800)$, and $7.45 \pm 0.05(\mathrm{n}=1,800)$, respectively. Every
7 to 10 days tanks were drained to $3 / 4$ of their total volume and filled with disinfected seawater (at $20 \mathrm{ppm}$ with calcium hypochlorite).

Shrimp suspected of IMNV infection were collected in the geographical area where the first case of the disease was reported in Brazil (city of Cajueiro da Praia, State of Piauí, Brazil; Nunes et al., 2004). Sampled shrimp were between 12 to $14 \mathrm{~g}$ in body weight and exhibited severe gross signs of IMNV infection (Lightner, 2004a,b; Nunes et al., 2004). Additionally, shrimp in the grow-out pond surveyed had attained a low final survival at harvest (32\%).

Soon after capture, shrimp pleopods were fixed in a $95 \%$ ethanol solution for PCR and real time RT-PCR analyses (Andrade et al., 2007). Shrimp samples were found to be negative for TSV, WSSV, and IHHNV, but positive for IMNV. Quantification of IMNV by real time RT-PCR indicated the sample contained $1.82 \times 10^{3}$ copies of IMNV/ $\mu \mathrm{L}$ RNA.

The per os viral challenge followed the methodology described by Hasson et al. (1995) and Wang et al. (1999), with minor modifications. Hasson et al. (1995) used inocula of Taura syndrome virus (TSV) to infect shrimp through intramuscular injection over three consecutive bioassays. Wang et al. (1999) challenged shrimp of 0.5, 6.4, and $5.0 \mathrm{~g}$ body weight with infected minced tissue contaminated with the white spot syndrome virus (WSSV) only on day 0 of rearing twice a day (from 5 to $10 \%$ of their body weight per feeding). In the present work, shrimp were challenged with IMNV over three consecutive days when they had reached between 4.9 and $6.9 \mathrm{~g}$ in body weight or 29 days after continuous exposure to the experimental diets. The amount of shrimp tissue fed to the animals was determined on a dry matter basis, according to estimated stocked shrimp biomass and the IMNV extract moisture level $(77.3 \pm 0.74 \%$; $n=5$ ). Feeding rates over the challenge period varied from 4.0 to $5.2 \%$ of estimated stocked shrimp biomass. During the viral challenge period, shrimp in treatments Com and Ref were fed their regular diets.

The PCR analysis performed on harvested shrimp indicated that animals of all treatments were IMNV-positive except those from the Com treatment. Therefore, shrimp from Ref were accidentally infected probably due to the sharing of common rearing equipment or through airborne transmission.

Some selected immunological parameters were evaluated in the following events: (1) two days before the per os IMNV challenge; (2) 17 days following the per os IMNV challenge; and (3) on shrimp harvest. In each sampling day, 30 shrimp per treatment (i.e., six animals per tank) were collected and $0.5 \mathrm{~mL}$ of their hemolymph was removed with a $1-\mathrm{mL}$ 
syringe to form six pools per treatment (each pool derived from one shrimp per tank). The pools were split into two samples; three for THC (total hemocyte count) and the other for the serum preparation used in the determination of protein concentration and phenoloxidase activity. After the hemolymph withdrawal, shrimp were returned to their respective tanks. Each individual was sampled only once during the study. In order to prevent recapture, sampled shrimp were tagged with a rubber ring placed at the base of their right penducular eye.

A sample of the shrimp hemolymph was withdrawn from the ventral region of the animal, between the last cephalothorax segment and the first abdominal segment. Just before the hemolymph puncture, the shrimp abdominal region was cleaned with a $70 \%$ ethanol solution. The collected hemolymph was kept cooled at $4{ }^{\circ} \mathrm{C}$ for $24 \mathrm{~h}$ to coagulate. Then, the sample was subjected to $-20{ }^{\circ} \mathrm{C}$ for $10 \mathrm{~min}$ and allowed to thaw soon afterwards. This process was repeated three consecutive times. The sample was then centrifuged three times at $16,000 \mathrm{~g}$ for $10 \mathrm{~min}$ to breakdown the hemocytes. The serum was collected, placed in an Eppendorf tube and stocked at $-20{ }^{\circ} \mathrm{C}$ until analysis.

To count the shrimp hemocytes, the hemolymph was collected directly in a 5\% formaldehyde solution plus anticoagulant $(27 \mathrm{mM}$ sodium citrate, $336 \mathrm{mM}$ sodium chloride, $115 \mathrm{mM}$ glucose, and $9 \mathrm{mM}$ EDTA; $\mathrm{pH}=7.6$ ), following dilution eight times. Total hemocyte count (THC) was carried out according to Moura et al. (2002). The protein concentration of the shrimp serum was determined through the Bradford Method (Bradford, 1976), using bovine serum albumin as the standard.

The phenoloxidase (PO) activity in the serum samples was measured spectrophotometricaly at $490 \mathrm{~nm}$ through the formation of the coral-red pigment DOPA-chrome. The serum samples were diluted $(1: 14)$ in TBS (trisbuffered saline) and one aliquot of $50 \mu \mathrm{L}$ of this solution was pre-incubated with the serine-protease trypsin (Sigma, $1 \mathrm{mg} / \mathrm{mL}$ ), for $5 \mathrm{~min}$ at $20^{\circ} \mathrm{C}$ to determine the PO activity (Maggioni et al., 2004). The serine-proteases are able to turn the zymogen proPO to the active PO. The inductor was replaced by an equivalent volume of TBS in the controls. After the incubation period, $50 \mu \mathrm{L}$ of L-DOPA $(3 \mathrm{mg} / \mathrm{mL})$ were added and the absorbance was read at $490 \mathrm{~nm}$ after $5,10,20$, and $30 \mathrm{~min}$. The specific PO enzymatic activity was expressed by the absorbance variation per min and per $\mathrm{mg}$ of the total protein in the samples. One unit of enzymatic activity represents the increase of absorbance in 0.001 per min and per mg of protein at $20^{\circ} \mathrm{C}$ (Söderhäll and Häll, 1984).
Statistical analyses were carried out with the Statistical Package for Social Sciences, v. 15.0.0 (SPSS Inc., Chicago, Illinois, USA). Analysis of variance (ANOVA) was used to determine the statistical differences between treatments. Turkey's multiple range test was used to examine if the individual differences between two means were significant at the 0.05 level.

\section{Results}

L. vannamei survival only started to decrease progressively after the per os challenge (Figure 1). Three days after exposure to IMNV extract, shrimp mortality in the IMNV-Ref treatment was already statistically different from all other treatments $(\mathrm{P}<0.05)$. This trend prevailed until shrimp harvest. Conversely, cumulative shrimp mortality did not vary significantly among treatments Com, Ref, and IMNV-BetG over the five weeks after the per os challenge $(\mathrm{P}>0.05)$.

A high mortality rate was observed three weeks subsequent to the viral challenge, regardless of the feed treatment. However, while cumulative mortality remained in the range of 29.6 (Com), 31.4 (IMNV-BetG), and 36.0\% (Ref), in the IMNV-Ref treatment, shrimp cumulative mortality reached $67.6 \%$.

Atharvest, the highest shrimp survival rate $(69.5 \pm 12.7 \%)$ was observed in the Com treatment (Figure 2), and it did

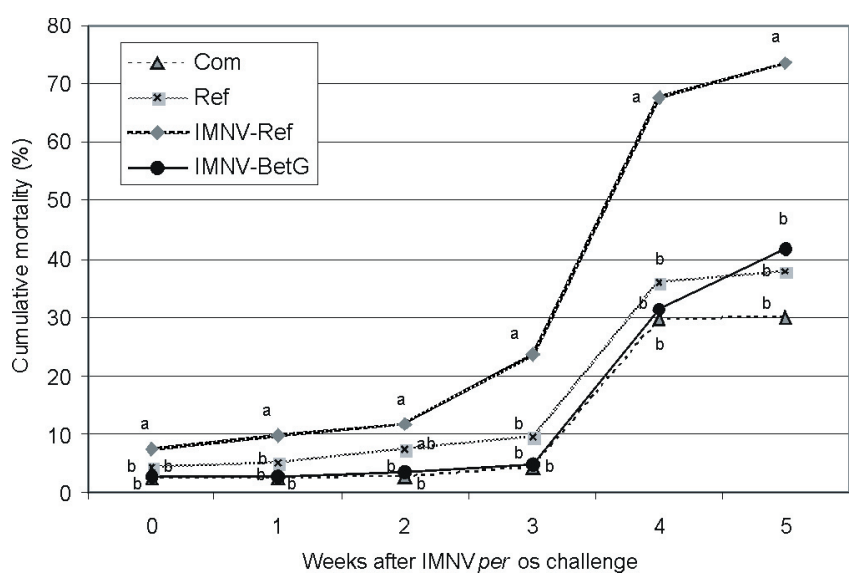

The " 0 " (zero) week refers to three days after the beginning of the per os viral challenge.

In each week, results that do not share the same letter are statistically different according to Turkey's multiple range test $(\mathrm{P}<0.05)$.

Com - commercial pelleted shrimp feed under no IMNV challenge; Ref - labmanufactured diet without $\beta-1,3 / 1,6$-glucan supplementation and no IMNV challenge; IMNV-Ref - same as Ref, but under IMNV challenge; IMNV-BetG lab-manufactured diet with $\beta$-1,3/1,6-glucan supplementation and under IMNV challenge.

Figure 1 - Cumulative mortality (\%) of L. vannamei juveniles $(2.6 \pm 0.4 \mathrm{~g})$ stocked in 500 -L polyethylene indoor tanks for 70 days and per os challenged with IMNV. 
not differ statistically from the Ref group (57.9 $\pm 9.21 \%)$. In contrast, the poorest survival $(23.2 \pm 5.76 \%)$ was reported for shrimp stocked in the IMNV-Ref treatment. Survival in IMNV-Ref was statistically different from that observed for Com and $\operatorname{Ref}(\mathrm{P}<0.05)$. In addition, shrimp survival for IMNV-BetG $(48.1 \pm 8.53 \%)$ was significantly higher than that found for IMNV-Ref. There was also no statistically significant difference in final shrimp survival between the Ref and IMNV-BetG groups ( $\mathrm{P}>0.05)$.

Shrimp grew continuously over the rearing period. Weekly growth rates varied from $0.56 \mathrm{~g}$ for the first 14 days of rearing to $0.77 \mathrm{~g}$ two weeks prior to harvest. At harvest, the highest shrimp body weight $(11.2 \pm 0.58 \mathrm{~g} /$ shrimp $)$ corresponded to the lowest survival rate (IMNV-Ref; Figure 2). Shrimp body weight in the IMNV-Ref was significantly higher than in the other remaining treatments (Com, Ref, and IMNV-Bet; $\mathrm{P}<0.05$ ). The final shrimp weights for Com $(9.8 \pm 0.54 \mathrm{~g})$ and $\operatorname{Ref}(9.9 \pm 0.19 \mathrm{~g})$ were not statistically different $(\mathrm{P}>0.05)$, while shrimp final weight for IMNV-BetG $(9.1 \pm 0.27 \mathrm{~g})$ was statistically lower than the Ref group $(\mathrm{P}<0.05)$.

Total hemocyte count was significantly affected by treatment and hemolymph sampling time (Table 3 ). There was a significant increase in shrimp THC, 17 days after the termination of the per os challenge $(\mathrm{P}<0.05)$, except for the Com and IMNV-BetG groups $(\mathrm{P}>0.05)$. At harvest, Ref's THC remained constant compared with the previous reading ( $\mathrm{P}>0.05)$, but reduced significantly for IMNV-Ref $(\mathrm{P}<0.05)$. Total hemocyte count for IMNV-BetG and Com exhibited no significant changes throughout the entire evaluation period $(\mathrm{P}>0.05)$.

Prior to the per os viral challenge, shrimp under the different treatments (Com, Ref, IMNV-Ref, and IMNV-BetG) displayed no significant differences in THC (P>0.05). After the viral challenge, THC for IMNV-BetG was significantly lower than Com and IMNV-Ref groups $(\mathrm{P}<0.05)$, but similar to the Ref group $(\mathrm{P}>0.05)$. No statistical difference was found for THC between the Com, Ref, and IMNV-Ref groups ( $P>0.05) 17$ days after the viral challenge. At harvest, THC was not significantly different among treatments (Com, Ref, IMNV-Ref, and IMNV-BetG; $\mathrm{P}>0.05$ ).

Serum protein concentration and phenoloxidase activity were unaffected by treatment or sampling time $(\mathrm{P}>0.05$; Table 3). However, both of these parameters reduced in relative terms 17 days post-infection for shrimp in groups Com, Ref, and IMNV-Ref group. After IMNV exposure, protein concentration and $\mathrm{PO}$ activity in shrimp under these treatments were 10.3 and $36.4 \%$ below the IMNV-BetG group.

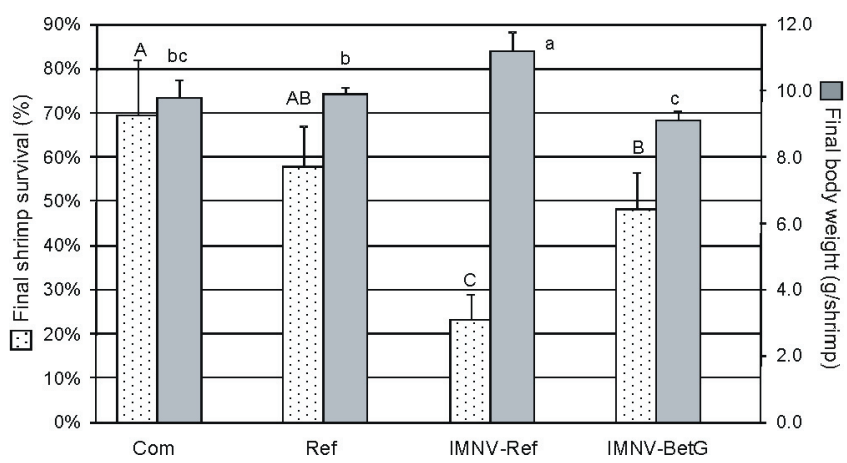

Values for each treatment are presented as means \pm standard error obtained from five replicate tanks.

Figure 2 - Mean survival (\%) and final body weight (g/shrimp) of L. vannamei juveniles $(2.6 \pm 0.4 \mathrm{~g})$ stocked in $500-\mathrm{L}$ polyethylene indoor tanks for 70 days and per os challenged with IMNV.

Table 3 - Total hemocyte count (cels $\left./ \mathrm{mm}^{3}\right)$, serum protein concentration $(\mathrm{mg} / \mathrm{L})$ and phenoloxidase activity (U/min $\left./ \mathrm{mg}\right)$ of $L$. vannamei reared for 70 days in 500-L indoor tanks, fed different diets and per os challenged with IMNV

\begin{tabular}{|c|c|c|c|c|c|c|c|c|c|}
\hline \multirow{2}{*}{ Treatment $^{1}$} & \multicolumn{3}{|c|}{ Total hemocyte count (cels/mm³) } & \multicolumn{3}{|c|}{ Serum protein concentration $(\mathrm{mg} / \mathrm{L})$} & \multicolumn{3}{|c|}{ Phenoloxidase activity (U/min/mg) } \\
\hline & Before $^{2}$ & After $^{3}$ & Harvest $^{4}$ & Before & After & Harvest & Before & After & Harvest \\
\hline Com & $19.934 \pm 4.147 \mathrm{Aa}^{5}$ & $27.243 \pm 5.577 \mathrm{Aa}$ & $25.667 \pm 7.088 \mathrm{Aa}$ & $114 \pm 5.1$ & $97 \pm 8.8$ & $103 \pm 12.3$ & $14.3 \pm 1.4$ & $14.6 \pm 5.5$ & $17.9 \pm 9.5$ \\
\hline Ref & $16.930 \pm 2.916 \mathrm{Aa}$ & $24.290 \pm 4.226 \mathrm{ABb}$ & $29.157 \pm 1.700 \mathrm{Ab}$ & $106 \pm 15.5$ & $98 \pm 15.3$ & $94 \pm 10.7$ & $23.8 \pm 1.4$ & $16.1 \pm 5.7$ & $27.0 \pm 4.2$ \\
\hline IMNV-Ref & $15.140 \pm 2.380 \mathrm{Aa}$ & $32.185 \pm 4.502 \mathrm{Ab}$ & $24.693 \pm 3.048 \mathrm{Ac}$ & $101 \pm 13.2$ & $96 \pm 5.0$ & $101 \pm 2.9$ & $23.0 \pm 5.1$ & $12.8 \pm 1.3$ & $17.4 \pm 5.5$ \\
\hline IMNV-BetG & $16.090 \pm 4.242 \mathrm{Aa}$ & $17.783 \pm 2.707 \mathrm{Ba}$ & $21.703 \pm 5.671 \mathrm{Aa}$ & $118 \pm 7.9$ & $107 \pm 10.9$ & $94 \pm 24.2$ & $18.8 \pm 6.7$ & $19.6 \pm 6.7$ & $24.8 \pm 17.0$ \\
\hline \multicolumn{10}{|c|}{ Two-way ANOVA P } \\
\hline Treatment & & $<0.001$ & & & $\mathrm{NS}^{6}$ & & & NS & \\
\hline Time & & $<0.001$ & & & NS & & & NS & \\
\hline Treatment $\times$ time & & $<0.001$ & & & NS & & & NS & \\
\hline
\end{tabular}

Data presented as mean \pm standard deviation. Readings were carried out in duplicate for each parameter.

${ }^{1}$ Com - commercial pelleted diet ( $350 \mathrm{~g} / \mathrm{kg}$ crude protein, CP); Ref - basal diet (314 g/kg CP lab-manufactured diet composed of fishmeal, soybean meal and wheat flour) fed to IMNV non-infected shrimp; IMNV-Ref - basal diet fed to IMNV per os challenged shrimp; IMNV-BetG - basal diet with 1,000 mg/kg of a commercial $\beta$-1,3/1,6-glucan source.

${ }^{2}$ Before - shrimp sampled two days prior to the per os challenge.

${ }^{3}$ After - shrimp sampling 17 days after termination of the per os challenge.

${ }^{4}$ Harvest - shrimp sampling on harvest (70th day of rearing);

${ }^{5}$ For a same immunological variable, results that do not share a same capital and lower case letter in rows and columns, respectively, are statistically different according to Turkey's multiple range test $(\mathrm{P}<0.05)$.

${ }^{6}$ Not statistically significant $(\mathrm{P}>0.05)$. 


\section{Discussion}

Although no $100 \%$ mortality rates were observed in the present study, the IMNV-Ref and IMNV-BetG animals were found to be very susceptible to IMNV. In the former, an average mortality rate as high as $76.8 \%$ was observed at harvest. Wang et al. (1999) reported 100\% mortalities after two weeks post-WSSV infection. Comparatively, in the present study, higher mortality rates were observed only three weeks after the per os IMNV challenge.

The high increase in shrimp mortality found in the fourth week after exposure to IMNV extract may have been due to some uncontrolled factor. Shrimp handling was required during periodic weighing. This may have acted as a stress factor contributing to a generalized increase in shrimp mortality after IMNV infection. It has been reported that shrimp handling is capable of producing stress and a decrease in survival rate. Mercier et al. (2006) were able to elicit a clear stress response in L. vannamei through daily voluntary manipulation of animals over a four-week period. Although in their work authors reported no statistically significant differences in shrimp immunological parameters, metabolic changes and a decrease in shrimp survival were detected in animals subjected to voluntary stress.

Andrade et al. (2007) injected an IMNV-diluted solution $\left(1.0 \times 10^{4}\right.$ copies of IMNV/ $\mu \mathrm{L}$ RNA $)$ in the third abdominal segment of SPF L. vannamei juveniles. First mortalities were observed just eight days post-infection, while a strong drop in shrimp survival was detected only 40 days later. The IMNV virulence of the present study and that of Andrade et al. (2007) is likely to have been different. These differences can be attributed to the viral load used, inoculum origin, challenge method, shrimp developmental stage, and degree of susceptibility at viral infection (Wang et al., 1999). While animals experimented by Andrade et al. (2007) were infected at $1.0 \mathrm{~g}$ body weight, in the present study shrimp were challenged at 4.9 to $6.9 \mathrm{~g}$. The delayed IMNV challenge carried out in the present study was necessary to allow the presumed stimulatory action in shrimp's immunological system.

In the present study, the higher mortalities rates were observed when animals attained close to $8.0 \mathrm{~g}$ in body weight. This observation is in agreement with reports from shrimp farmers from Northeast Brazil. In infected areas, although clear signs of IMNV can be found in shrimp of all size ranges, the highest mortality rates are most often observed when animals reach between 6 and $8 \mathrm{~g}$ in body weight (Nunes et al., 2004). In the present study, virus propagation may have been favored by cannibalism.
Although dead shrimp were collected daily, rarely were dead animals found intact.

In the present study, shrimp survival in the IMNVBetG group was significantly higher than the one observed for the IMNV-Ref group $(\mathrm{P}<0.05)$. The composition of the diet fed to shrimp under these groups was the same, except in regard to the inclusion of $0.1 \%$ of a commercial $\beta-1,3 /$ 1,6 -glucan source. Shrimp were also equally challenged with IMNV infected tissue. This strongly suggests that a continuous exposure to a $\beta-1,3 / 1,6$-glucan supplemented diet enhanced $L$. vannamei survival after per os challenge with IMNV.

Other studies have also reported a positive effect of betaglucans on shrimp survival. Chang et al. (2000) reported that Penaeus monodon broodstock fed betaglucansupplemented diets reached higher survival rates when compared with a control group. Rodríguez et al. (2007) also found an increase in $L$. vannamei survival after rearing larvae in 0.2-ha ponds that had been exposed to a combination of probiotics and $\beta$-1,3/1,6-glucans for 15 days before a per os challenge with WSSV (White spot syndrome virus).

In the present study, shrimp weight gain was similar to other studies carried out in our lab with $L$. vannamei reared under a time-restrictive feeding schedule (Nunes et al., 2006). However, the alleged effect of $\beta-1,3 / 1,6-$ glucans on shrimp growth performance was unclear due to the significant mortalities observed. Shrimp growth was directly affected by survival. Shrimp with less than $10 \mathrm{~g}$ of final body weight were found in treatments with the highest survival rates (Com, Ref and IMNV-BetG). On the other hand, the final weight of the IMNV-Ref shrimp, which had the lowest survival rate, was the highest. The inverse relationship between shrimp growth and stocking density is widely known (Sandifer et al., 1988; Ray and Chien, 1992).

In the present study, no significant difference was observed in shrimp survival between groups Ref and IMNVBetG. However, the IMNV-BetG shrimp final weight was statistically lower than that of Ref shrimp $(\mathrm{P}<0.05)$. If shrimp growth was affected solely by survival rate, similar body weights would be expected for these two treatments. The deliberate IMNV challenge of the IMNV-BetG group probably impaired their growth rate. Moribund or sick shrimp divert some body energy to produce immunological responses, and as such, a growth depression is often reported (Pascual et al., 2006).

The literature reports conflicting results on the effect of betaglucans on shrimp growth. While some studies have not found any adverse effect of betaglucan on shrimp growth 
(Song et al., 1997), others indicate a growth-enhancing effect (Itami et al., 1998; López et al., 2003). In our study, rearing $L$. vannamei with a diet containing $\beta-1,3 / 1,6$-glucan under a continuous feeding regime did not cause any noticeable growth depression. However, we propose new studies to be carried out in order to clarify this issue.

Although some authors (Chang et al., 2000; López et al., 2003) have suggested that a continuous exposure to betaglucans can result in immunological fatigue, our results do not indicate the same. In spite of the lack of statistical significance, even at harvest shrimp from IMNV-BetG had a phenoloxidase activity $38.5 \%$ higher than the Com group. This finding suggests that the immunological responses in IMNV-BetG shrimp persisted, even after a long period after betaglucan allowance. This result is in agreement with López et al. (2003), who reported that 40 days after L. vannamei juveniles were fed a diet with $2,000 \mathrm{mg} / \mathrm{kg}$ of $\beta$-1,3-glucan, there was a positive response to a salinity shock.

However, according to Chang et al. (2000), the continuous exposure to betaglucan-supplemented diets may lead to immunological fatigue in shrimp. These authors reported that 24 days after exposure to diets containing $2,000 \mathrm{mg} / \mathrm{kg}$ of $\beta$-1,3-glucan, Penaeus monodon broodstock $(135 \pm 25 \mathrm{~g})$ showed a reduction in phagocytic activity and in the production of $\mathrm{O}_{2}$ in the hemolymph. Authors proposed a maximum period of three weeks for betaglucan allowance or the adoption of an intermittent feeding regime, with 20 days on followed by 10 days off.

During an infection, a specific $\beta$-1,3-glucan-binding protein $(\beta \mathrm{GBP})$ in the crustacean plasma first recognizes and binds to the pathogen cell wall. Then, the hemocytes respond to the $\beta \mathrm{GBP}$ complex with glucans by degranulation and release of the proPO system (Johansson et al., 2000). Thus, an increase in the phenoloxidase activity (PO) for the IMNV-BetG shrimp was expected, particularly because shrimp under this group achieved a survival significantly higher than the IMNV-Ref shrimp. The $44.3 \%$ drop in PO activity after IMNV challenge in the IMNV-Ref group suggests a strong depression in their immunological responses. Under a similar condition, the IMNV-BetG group exhibited a $4.2 \%$ increase in PO activity.

The decapod crustacean hemocytes are considered their first organic defense since they act directly in processes of recognition, processing, and amplification of the immunological response (Johansson and Söderhäll, 1988). In the present study, the increase in THC observed for Com, Ref, and IMNV-Ref may be related to the sampling time. Shrimp hemolymph was sampled only 17 days after the termination of the per os viral challenge. Thus, it is possible that the shrimp immunological system had sufficient time to return to its basal status. The same response pattern was observed in L. vannamei juveniles, 14 days after eyestalk ablation, although the THC increase was not significant (Maggioni et al., 2004). Song et al. (2003) reported that $L$. vannamei infected by the Taura virus produced a THC 79\% lower than non-infected shrimp. As a general rule, the THC falls when crustaceans suffer stress, as when facing viral infection (Hennig et al., 1998; Lorenzo et al., 1999; Cheng and Chen, 2001). In the present study, THC in the IMNVBetG group showed no variation throughout the culture system and remained below observed values for groups Com and IMNV-Ref. The immunological results found in the present study suggest a positive action of a dietary $\beta-1,3 / 1,6$-glucan on L. vannamei survival subsequent to a per os challenge with IMNV.

\section{Conclusions}

Addition of $1,000 \mathrm{mg} / \mathrm{kg}$ of $\beta-1,3 / 1,6$-glucan to diets for $L$. vannamei enhances shrimp survival orally exposed to Infectious myonecrosis virus. No signs of immunological fatigue or detriment in growth can be detected when the species is continually exposed to this diet.

\section{Acknowledgments}

The first author was supported by Fundação Cearense de Apoio ao Desenvolvimento Científico e Tecnológico - FUNCAP (Fortaleza, Brazil) through a MSc fellowship grant. This work was funded by Financiadora de Estudos e Projetos - FINEP (Rio de Janeiro, Brazil, Grant No. 01.05.0738.00, FAP CT Verde Amarelo/34). The last author acknowledges the support received through a researchproductivity fellowship (CNPq/MCT, PQ\# 305513/2012-5).

\section{References}

Andrade, T. P. D.; Srisuvan, T.; Tang, K. F. J. and Lightner, D. V. 2007. Real-time reverse transcription polymerase chain reaction assay using TaqMan probe for detection and quantification of Infectious myonecrosis virus (IMNV). Aquaculture 264:9-15.

AOAC - Association of Official Analytical Chemistry. 1990 Official methods of analysis. 15th ed. AOAC International, Arlington, VA.

Bradford, M. M. 1976. A refined and sensitive method for the quantification of microgram quantities of protein using the principle of protein-dye binding. Analytical Biochemistry 72:248.

Browdy, C. L.; Bharadwaj, A. S.; Venero, J. A. and Nunes, A. J. P. 2012. Supplementation with 2-hydroxy-4-(methylthio) butanoic acid (HMTBa) in low fish meal diets for the white shrimp, Litopenaeus vannmei. Aquaculture Nutrition 18:432-440. 
Chang, C. F.; Chen, H. Y.; Su, M. S. and Liao, I. -C. 2000. Immunomodulation by dietary $\beta-1-3$ glucan in the brooders of the black tiger shrimp Penaeus monodon. Fish and Shellfish Immunology 10:505-514.

Cheng, W. and Chen, J. C. 2001. Effects of intrinsic and extrinsic factors on the haemocyte profile of the prawn, Macrobrachium rosenbergii. Fish Shellfish Immunology 11:53-63.

Chotigeat, W.; Tongsupa, S.; Supamataya, K. and Phongdara, A. 2004. Effect of fucoidan on disease resistance of black tiger shrimp. Aquaculture 233:23-30.

Couch, J. A. 1974a. An ezootic nuclear polyhedrosis virus of pink shrimp: ultrastructure, prevalence, and enhancement. Journal of Invertebrate Pathology 24:311-331.

Couch, J. A. 1974b. Free and occluded virus similar to Baculovirus in hepatopancreas of pink shrimp. Nature 247:229-331.

Hasson, K. W.; Lightner, D. V.; Poulos, B. T.; Redman, R. M.; White, B. L.; Brock, J. A. and Bonami, J. R. 1995. Taura Syndrome in Penaeus vannamei: demonstration of a viral etiology. Diseases of Aquatic Organisms 23:115-126.

Hennig, O.; Itami, T.; Maeda, M.; Kondo, M.; Natuskari, Y. and Takahashi, Y. 1998. Analyses of hemolymph immunoparameters in Kuruma shrimp infected with penaeid rod-shaped DNA virus. Fish Pathology 33:389-393.

Huang, C. -C. and Song, Y. L. 1999. Maternal transmission of immunity to white spot syndrome associated virus (WSSV) in shrimp (Penaeus monodon). Developmental and Comparative Immunology 23:545-552.

Itami, T.; Asano, M.; Tokushige, K.; Jubono, K.; Nakagawa, A.; Takeno, N.; Nishimura, H.; Maeda, M.; Kondo, M. and Takahashi, Y. 1998. Enhancement of disease resistance of Kuruma shrimp, Penaeus japonicus, after oral administration of peptidoglycan derived from Bifidobacterium thermophilum. Aquaculture 164:277-288

Johansson, M. W. and Söderhäll, K. 1988. Isolation and purification of a cell adhesion factor from crayfish blood cells. Journal of Cell Biology 106:1795-1803.

Johansson, M. W.; Keyser, P.; Sritunyalucksana, K. and Söderhäll, K. 2000. Crustacean haemocytes and haematopoisis. Aquaculture 191:45-52.

Karzinkin, G. S. and Tarkovskaya, O. I. 1964. Determination of caloric value of small samples. p.122-124. In: Techniques for the investigation of fish physiology. Pavloskii, E. N., ed. Oldbourne Press, London.

Lightner, D. V. 1996. A handbook of shrimp pathology and diagnostic procedures for diseases of cultured penaeid shrimp. The World Aquaculture Society, Baton Rouge, Louisiana.

Lightner, D. V. 2003. Exclusion of specific pathogens for shrimp disease prevention. p.81-116. In: Biosecurity in aquaculture production systems: exclusion of pathogens and other undesirables. Lee, C.-H. and O'Bryen, P. J., eds. The World Aquaculture Society, Baton Rouge, Louisiana.

Lightner, D. V.; Hedrick, R. P.; Fryer, J. L.; Chen, S. N.; Liao, I. C. and Kou, G. H. 1987. A survey of cultured penaeid shrimp in Taiwan for viral and other important diseases. Fish Pathology 22:127-140.

Lightner, D. V.; Pantoja, C. R.; Poulos, B. T.; Tang, K. F. J.; Redman, R. M.; Andrade, T. P. and Bonami, J. R. 2004a. Infectious Myonecrosis (IMN): a new virus disease of Litopenaeus vannamei. p.353. In: Aquaculture 2004 Book of Abstracts of Aquaculture. The World Aquaculture Society, Baton Rouge, Louisiana.

Lightner, D. V.; Pantoja, C. R.; Poulos, B. T.; Tang, K. F. J.; Redman, R. M.; Andrade, T. P. and Bonami, J. R. 2004b. Infectious myonecrosis: new disease in Pacific white shrimp. Global Aquaculture Advocate 7:85.

Lin, C. K. 1989. What went wrong? World Aquaculture 20:19-20.

Lo, C. F.; Leu, J. H.; Ho, C. H.; Chen, C. H.; Peng, S. E.; Chen, Y. T.; Chou, C. M.; Yeh, P. Y.; Huang, C. J.; Chou, H. Y.; Wang, C. H. and Kou, G. H. 1996. Detection of baculovirus associated with white spot syndrome (WSBV) in penaeid shrimps using polymerase chain reaction. Diseases of Aquatic Organisms 25:133-141.
López, N.; Cuzon, G.; Gaxiola, G.; Taboada, G.; Valenzuela, M.; Pascual, C.; Sánchez, A. and Rosas, C. 2003. Physiological, nutritional, and immunological role of dietary $\beta$-1,3-glucan and ascorbic acid 2-monophosphate in Litopenaeus vannamei juveniles. Aquaculture 224:223-243.

Lorenzo, S.; Guarrini, S.; Smith, V. J. and Ferrero, E. A. 1999. Effects of LPS injection on circulating hemocytes in crustaceans in vivo. Fish and Shellfish Immunology 9:31-50.

Maggioni, E. S.; Andreatta, E. R.; Hermes, E. M. and Barracco, M. A. 2004. Evaluation of some hemato-immunological parameters in female shrimp Litopenaeus vannamei submitted to unilateral eyestalk ablation in association with a diet supplemented with superdoses of ascorbic acid as a form of immunostimulation. Aquaculture 241:501-515.

Mercier, L.; Palacios, E.; Campa-Córdova, Á. I.; Tovar-Ramírez, D.; Hernández-Herrera, R. and Racotta, I. S. 2006. Metabolic and immunological responses in Pacific whiteleg shrimp Litopenaeus vannamei exposed to a repeated handling stress. Aquaculture 258:633-640.

Moura, R. A.; Purchio, A. and Almeida, T. V. 2002. Técnicas de laboratório. 3.ed. Atheneu, Rio de Janeiro.

Nunan, L. M.; Poulos, B. T. and Lightner, D. V. 1998. Reverse transcription polymerase chain reaction (RT-PCR) used for the detection of Taura Syndrome Virus (TSV) in experimentally infected shrimp. Diseases of Aquatic Organisms 34:87-91.

Nunan, L. M.; Poulos, B. T. and Lightner, D. V. 2000. Use of polymerase chain reaction for the detection of infectious hypodermal and hematopoietic necrosis virus in penaeid shrimp. Marine Biotechnology 2:319-328.

Nunes, A. J. P.; Martins, P. C. C. and Gesteira, T. C. V. 2004 Carcinicultura ameaçada: produtores sofrem com as mortalidades decorrentes do vírus da Mionecrose Infecciosa (IMNV). Panorama da Aquicultura 14:37-51.

Nunes, A. J. P. and Parsons, G. J. 2000. Size-related feeding and gastric evacuation measurements for the Southern brown shrimp Penaeus subtilis. Aquaculture 187:133-151.

Nunes, A. J. P.; Sá, M. V. C.; Carvalho, E. A. and Sabry-Neto, H. 2006. Growth performance of the white shrimp Litopenaeus vannamei reared under time- and rate-restriction feeding regimes in a controlled culture system. Aquaculture 253:646-652.

Pascual, C.; Rodríguez, T. and Rosas, C. 2006. Inmunidad y nutrición. p.294-318. In: Rosas, C.; Carrilo, C.; Wilson, R. and Andreatta, E. R., eds. Estado Actual y Perspectivas de la Nutrición de los Camarones Peneidos Cultivados en Iberoamérica. Publidisa Mexicana SA de CV, México DF.

Poulos, B. T. and Lightner, D. V. 2006. Detection of infectious myonecrosis virus (IMNV) of penaeid shrimp by reversetranscriptase polymerase chain reaction (RT-PCR). Diseases of Aquatic Organisms 73:69-72.

Poulos, B. T.; Tang, K. F. J.; Pantoja, C. R.; Bonami, J. R. and Lightner, D. V. 2006. Purification and characterization of infectious myonecrosis virus of penaeid shrimp. Journal of General Virology 87:987-996.

Raa, J. 2000. The use of immune-stimulants in fish and shellfish feeds. p.47-56. In: Avances en Nutrición Acuícola V. Memorias del Quinto Simposio Internacional de Nutrición Acuícola. Cruz-Suárez, L. E.; Ricque-Marie, D.; Tapia-Salazar, M.; Olvera-Novoa, M. A. and Civera-Cerecedo, R., eds. Mérida, Yucatán.

Raa, J. 2003. Beta-1,3/1,6-glucanos: la ciencia moderna y la sabiduia antigua se combinan en beneficio de la acuacultura. Panorama Acuícola 8:28-29.

Ray, W. M. and Chien, Y. H. 1992. Effects of stocking density and aged sediment on tiger prawn, Penaeus monodon, nursery systems. Aquaculture 104:231-248.

Rodríguez, J.; Espinosa, Y.; Echeverría, F.; Cárdenas, G.; Román, R. and Stern, S. 2007. Exposure to probiotics and $\beta-1,3 / 1,6$-glucans in larviculture modifies the immunological response of Penaeus vannamei juveniles and both the survival to White Spot Syndrome Virus challenge and pond culture. Aquaculture 273:405-415. 
Sandifer, P. A.; Hopkins, J. S. and Stokes, A. D. 1988. Intensification of shrimp culture in earthen ponds in South Carolina: progress and prospects. Journal of the World Aquaculture Society 19:218-226.

Seljelid, R.; Bögwald, J. and Lundwall, Å. 1981. Glycan stimulation of macrophages in vitro. Experimental Cell Biology 131:121-129.

Senapin, S.; Phewsaiya, K.; Briggs, M. and Flegel, T. W. 2007. Outbreaks of infectious myonecrosis virus (IMNV) in Indonesia confirmed by genome sequencing and use of an alternative RT-PCR detection method. Aquaculture 266:32-38.

Söderhäll, K. and Hall, L. 1984. Lipopolysaccharide-induced activation of prophenoloxidase activating system in crayfish haemocyte lysate. Biochimica Biophysica Acta 797:99-104.

Song, Y. L.; Liu, J. J.; Chan, L. C. and Sung, H. H. 1997. Glucaninduced diesease resistance in tiger shrimp (Penaeus monodon). p.413-421. In: Fish vaccinology. Gudding, R.; Lillehaug, A.; Midtlyng, P. J. and Brown, F., eds. Karger AG, Basel.

Song, Y. L.; Yu, C. I.; Lien, T. W.; Huang, C. C. and Lin, M. N. 2003. Haemolymph parameters of Pacific white shrimp (Litopenaeus vannamei) infected with Taura syndrome virus. Fish and Shellfish Immunology 14:317-331.

Sritunyalucksana, K.; Sithisarn, P.; Withayachumnarnkul, B. and Flegel, T. W. 1999. Activation of prophenoloxidase, agglutinin and antibacterial activity in haemolymph of the black tiger prawn, Penaeus monodon, by immunostimulants. Fish and Shellfish Immunology 9:21-30

Sung, H. H.; Kou, G. H. and Song, Y. L. 1994. Vibriosis resistance induced by glucan treatment in tiger shrimp (Penaeus monodon). Fish Pathology 29:11-17.

Takahashi, Y.; Kondo, M.; Itami, T.; Honda, T.; Inagawa, H.; Nishizawa, T.; Soma, G-I. and Yokomizo, Y. 2000. Enhancement of disease resistance against penaeid acute viraemia and induction of virus-inactivating in haemolymph of kuruma shrimp, Penaeus japonicus, by administration of Pantoea agglomerans lipopolysaccharide (LPS). Fish and Shellfish Immunology 10:555-558

Tang, K. F. J.; Pantoja, C. R.; Poulos, B. T.; Redman, R. M. and Lightner, D. V. 2005. In situ hybridization demonstrates that Litopenaeus vannamei, L. stylirostris and Penaeus monodon are susceptible to experimental infection with infectious myonecrosis virus (IMNV). Diseases of Aquatic Organisms 63:261-265.

Wang, Q.; White, B. L.; Redman, R. M. and Lightner, D. V. 1999. Per os challenge of Litopenaeus vannamei postlarvae and Farfantepenaeus duorarum juveniles with six geographic isolates of white spot syndrome virus. Aquaculture 170:179-194. 